\title{
Covid-19 Pandemisinin BIST Sektör Endeksleri İle İlişkisi: Bayer - Hanck (2013) Eşbütünleşme Analizi (The Relationship of the Covid-19 Pandemic with BIST Sector Indices: Bayer - Hanck (2013) Cointegration Analysis)
}

\author{
Ayşegül ERTUĞRUL AYRANCI ${ }^{\text {iD }}$ a Gizem ARI ${ }^{(i)}$ b \\ a İstanbul Gelişim Üniversitesi, Uygulamalı Bilimler Fakültesi, İstanbul, Türkiye, aertugrul@gelisim.edu.tr \\ b Beykent Üniversitesi, İktisadi ve İdari Bilimler Fakültesi İstanbul, Türkiye, gizemari@beykent.edu.tr
}

MAKALE BİLİSi
Anahtar Kelimeler:
Covid-19
BİST Sektör Endeksleri
Eşbütünleşme Analizi

Gönderilme Tarihi 14
Eylül 2021
Revizyon Tarihi 17 Aralık
2021
Kabul Tarihi 21 Aralık
2021

Makale Kategorisi: Araştırma Makalesi

\section{ÖZET}

Amaç - Dünya ülkelerini beklenmedik bir şekilde etkileyen Covid-19 pandemisi, ölüm ve hastalıkların yanı sıra ciddi ekonomik kayıplara da yol açmıştır. Genel olarak değerlendirildiğinde, Covid-19 pandemisinin her sektörü eşit seviyede etkilemediği, birtakım sektörlerin söz konusu olumsuzluğu fırsata çevirirken birtakım sektörlerin ise iflas noktasına geldiği görülmektedir. Bu araştırmanın temel hedefi, BiST sektörel endeksleriyle Covid-19 vaka sayıları arasındaki ilişkiyi araştırmaktır. Böylece incelenen dönem için hangi sektörlerin daha fazla olumsuz etkiye sahip olduğu ortaya konacaktır.

Yöntem - 13.03.2020 - 07.05.2021 tarihleri arasında haftanın 5 gününü içeren günlük veriler için covid vaka sayısı ve BİST sektör endeksleri arasındaki ilişkiler uzun ve kısa dönem olarak ele alınmıştır. Araştırmada verilerin durağanlığını test etmek amacıyla Augmented Dickey-Fuller (ADF) ve Phillips-Perron (PP) testleri kullanılmıştır. Denklem sistemindeki değişkenlerin ortak gecikme uzunluklarını belirlemek için Son Tahmin Hatası (FPE), Hannan-Quinn (HQ), Schwarz (SW), Olabilirlik Oranı (LR) ve Akaike Bilgi Kriterleri (AIC) kullanılmıştır. Uzun dönemli ilişkileri belirlemek için Bayer-Hanck (2013) Eşbütünleşme Analizi ve kısa dönemli ilişkileri belirlemek için ise hata düzeltme modeli kullanılmıştır.

Bulgular - Analiz sonucunda, mali endeks haricinde diğer sektör endeksleri ve covid vaka sayıları arasında uzun dönemli anlamlı ilişki belirlenmiştir. Ayrıca, Covid vaka sayılarının diğer endekslere göre en çok sanayi endeksini olumsuz etkilediği görülmüştür.

Tartışma - Sonuçlar BİST sektör endekslerinin pandemi sürecinde düşüş yaşadığını göstermiştir. Pandemiden kaynaklı belirsizlik artışları, aynı zaman oynaklık artışını da berbarinde getirerek yatırımcıların riskten kaçınma düzeylerinin artmasına sebep olmauştur. Bununla birlikte, beklenmedik bir dış etki olarak pandemi küresel çapta finansal piyasaların gerilemesine sebebiyet vermiştir. Salgının boyutu ve uzun vadeli mali etkileri düşünüldüğünde, gelir transferleri, borç ertelemeleri, vergi/kredi kolaylıkları, doğrudan fonlama ve garantili borç şeklinde tedbirlerin artırılması gerektiği açıktır.

ARTICLE INFO
Keywords:
Covid-19
BIST Sector Indices
Cointegration Analysis

Received 14 September 2021

Revised 17 December 2021

Accepted 21 December 2021

\section{ABSTRACT}

Purpose - The Covid-19 pandemic, which unexpectedly affected the all of the world, caused serious economic losses as well as death and disease. When evaluated in general, it is seen that the Covid-19 pandemic did not affect every sector equally, while some sectors turned the said negativity into an opportunity, while some sectors came to the point of bankruptcy. The main goal of this research is to investigate the relationship between BIST sectoral indexes and the number of Covid-19 cases. Thus, it will be revealed which sectors have more negative effects for the examined period.

Design/methodology/approach - For the daily data including 5 days of the week between 13.03.2020 07.05.2021, the relations between the number of covid and BIST sector indices are considered as long and short term. Augmented Dickey-Fuller (ADF) and Phillips-Perron (PP) tests were used to test the stationarity of the data. Final Prediction Error (FPE), Hannan-Quinn (HQ), Schwarz (SW), Likelihood Ratio (LR) and Akaike Information Criteria (AIC) were used to determine the common lag lengths of the variables in the equation system. Bayer-Hanck (2013) Cointegration Analysis was used to determine long-term relationships and error correction model was used to determine short-term relationships.

Article Classification: Research Article

Results - As a result of the analysis, a long-term significant relationship was determined between the other sector indices and the number of covid cases, except for the financial index. In addition, it was observed that the number of Covid cases affected the industry index the most compared to other indexes.

Discussion - The results showed that the BIST sector indices experienced a decline during the pandemic process. Uncertainty increases due to the pandemic also brought increased volatility, leading to an increase in investors' risk aversion. However, as an unexpected external effect, the pandemic caused a recession in global financial markets. Considering the extent of the epidemic and its long-term financial effects, it is clear that measures in the form of income transfers, debt postponements, tax/credit facilities, direct funding and guaranteed debt should be increased. 


\section{GIRİŞ}

Geçmişten günümüze kadar meydana gelen krizlerde finansal piyasalar için önem arz eden göstergelerden birisi olan hisse senedi piyasaları, finansal aktörler açısından ekonominin seyri konusunda bilgi verici olmaktadır. Covid-19 korona virüs salgınıyla beraber meydana gelen yüksek belirsizlik ve endişe koşullarında, hisse senedi piyasalarında da oldukça kritik değişiklikler ortaya çıkmıştır. Finansal aktörler tarafından hissedilen geleceğe ilişkin kaygılar, dünyanın önde gelen borsalarında da yüksek dalgalanmalara yol açmiştır.

Covid-19 salgını tarafından yaratılan bütün etkilerin boyutlarını bugünden tespit etmek mümkün olmamakla beraber, söz konusu salgının finansal faaliyetler üzerinde kritik etkilerinin bulunduğu gözlenmektedir (He vd., 2020: 276). Ülkelerde, vaka sayıları ve ölüm oranlarının günden güne artması ile beraber ülke seviyesinde salgını kontrol altına alabilmek açısından sosyal mesafeye uyum, sokağa çıkma kısıtlaması, şüpheli vakalara testlerin yapılması ve karantina altına alınması, doğruluğu ispatlanmış vakaların tedavisine başlanmasına ilişkin faaliyetlere benzer acil durum tedbirleri alınmıştır. Fakat söz konusu önlemler, finansal anlamdaki kaygıların artmasının önüne geçememiştir. Bu kaygılar ile beraber pek çok ülkelerin hükümetleri tarafından, maliye bakanlıklarından merkez bankalarına kadar, finansal zararları kontrol altında tutabilmek bakımından destek ve teşvik paketlerinin açılanması söz konusu olmuştur (Ashraf, 2020: 2).

Yaşanılan koronavirüs salgını, iyi sağlık seyrinin ekonomik faaliyetlerin ve ekonomik büyümenin ana motoru olduğunun bir kanıtı olduğunu göstermiştir (Bloom \& Canning, 2000: 1207). Salgınının ortaya çıkmasından bu yana, küresel borsalar trilyon dolarlık kayıplarla karşılaşmıştır. Bunun nedeni, borsaların ve ekonomik faaliyetlerin, küresel borsaları ve finansal piyasaları eriten 2008 mali krizi gibi çeşitli risklerle dolu olmasından kaynaklanmaktadır (Dang \& Nguyen, 2020: 4). Mevcut covid-19 benzeri hastalık salgınları gibi beklenmedik olaylardan kaynaklanan risk, borsalarda yıkıma yol açmaktadır. Bu nedenle borsa analistleri, salgını durdurmak için çözümler ertelenirse, mevcut covid-19'un 2008 küresel mali krizinden bu yana küresel borsalar için en büyük engeli oluşturabileceğini tahmin etmektedir (Srivastava, 2020: 386).

Covid-19 yayılımı dolayısıyla, OECD 2020 yılı küresel bazdaki ekonomik anlamda büyüme tahmini görünümünü yüzde 2,9'dan yüzde 2,4'e değiştirmesine neden olmuş, ancak koronavirüs yayılımının yoğunlaştırılması durumunda büyümenin 2020' de yüzde 1,5'e düşebileceğinin altını çizmiştir (OECD, 2020). Yeni covid-19, Çin'de ve dünyanın diğer ülkelerinde insanların seyahatleri, mal ve hizmetlerin hareketi, üretimde azalmayla birlikte fabrikaların kapanması ve içeride kalma siparişleriyle talebin düşmesi ile ilgili çeşitli kısıtlamalara neden olmuştur. Covid-19 hareket kısıtlamaları, turizm ve iş ziyaretlerine, pazarlama ve tedarik zincirlerine, hisse senetlerine ve tahvillere dokunarak ve borsa güveninde hizlanan düşüşe değinerek dünyanın geri kalanına yansımaktadır (OECD, 2020). Literatüre bakıldığında araştırmacılar, önceki salgınlar sonucunda pandemi yaratan hastalığın borsa ve genel ekonomi üzerindeki etkisi hakkında çeşitli sonuçlara ve varsayımlara sahip olmuşlardır. Bazı araştırmacılar, pandemilerin tüm ekonomi için mutlak bir felakete yol açmayabileceği sonucuna varırken, bazıları ise, önceki yaşanan salgınların (SARS, MARS vb.) Asya'daki gibi bölgesel borsaları zayıflattığını iddia etmişlerdir.

Covid-19 salgını ile beraber gelen pandemi, bütün dünya genelinde işletmelerin kapanması, üretimin durması veya yavaşlaması, tüketimin azalması ve işsizlik oranlarının artması şeklinde olumsuzluklara yol açmaktadır (Chaouachi \& Chaouachi, 2020: 3). Salgın sonucunda meydana gelen finansal etkiler, ülkelerde ve sektörlerde yakından hissedilmekte ve bunun sonucunda finansal piyasalar da olumsuz yönde etkilenmektedir. Covid19 salgını bütün sektörlere eşit seviyelerde etki etmemiştir. Kimi sektörler tarafından söz konusu salgın fırsata çevirilirken, kimi sektörler ise iflasın eşiğine gelmiştir. Yapılan araştırmanın temel hedefi, BİST sektörel endekslerinden olan finansal endeks, hizmet endeksi, sanayi endeksi, turizm endeksi ve ulaştırma endeksiyle Covid-19 vaka sayıları arasındaki ilişkiyi Bayer-Hanck (2013) Eşbütünleşme Analizi yardımıyla araştırmaktır. Böylece ele alınan dönem için, hangi sektörlerde daha fazla olumsuz etki oluştuğu ortaya konulacaktır. 


\section{KAVRAMSAL ÇERÇEVE}

\subsection{Covid-19 ve Hisse Senedi Piyasalarına Etkileri}

Covid-19 salgınının yol açmış olduğu endişe, dünya borsalarında da ilerlemenin yönünün negatif olmasına yol açmıştır. Mart 2020 tarihi itibariyle, finans piyasalarında çok ciddi düşüşlerin yaşandığı gözlenmiştir. Söz konusu düşüşlerin ilk etkileri, ABD'de S\&P 500, Japonya'da Nikkei, Güney Kore'de Kosdaq, İngiltere' de FTSE 100 Endeksleri şeklindeki finansal piyasalar için benchmark olarak kabul görmüş göstergelerde çarpıcı biçimde görülmüştür. Yatırımcılar tarafından borsada, potansiyel düşüşe yönelik tedirginlik hissedildiğinde, mevcut varlıkların değerinin korunması açısından portföylerin sigortalanması için opsiyon mekanizması kullanılmaktadır. Artan taleple birlikte opsiyon fiyatlarının da aratacağı ve bunun paralelinde VIX Korku endeksinin değerinde artış yaşanacağ ve endişeler, VIX endeksinin artmasına yol açmaktadır.

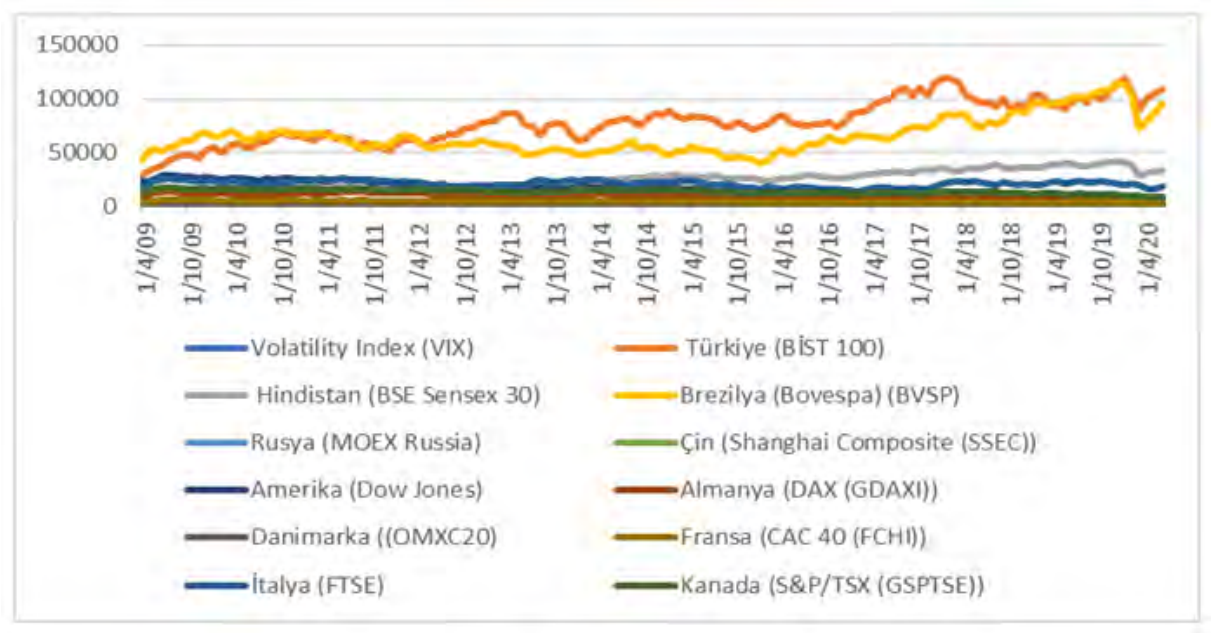

Şekil 1: Ülkelere Yönelik Borsa Endekslerinin Görünümü (1/4/2009-1/4/2020)

Şekil 1'de seçilmiş bazı ülkelerin borsa endeksleri ele alınmıştır. Görüleceği üzere, Nisan 2020 itibariyle keskin bir düşüş gözlenmektedir. Mart 2020 sonrasında en fazla ölüm vakasının meydana geldiği ilk beş ülkeyi sırayla ABD, Hindistan, Brezilya, Rusya ve Kolombiya şeklinde sıralamak mümkündür. ABD Dow Jones Endeksi'nde virüsün yayılması ile birlikte ciddi düşüşler meydana gelmiştir ve Mart 2020'ye gelindiğinde ise son 3 senenin en düşük seviyesinde gerçekleştiği görülmüştür. Hindistan'ın en popüler endekslerinden olan BSE Sensex Endeksi'nde, salgın boyunca meydana gelen olumsuz durumlar nedeniyle 2017 senesinden günümüze kadar olan en düşük seviye 2020'nin Mart ayında gözlenmiştir. Brezilya Bovespa Endeksi, ülkenin her yanında ortaya çıkan Covid-19 ölümleri ile beraber 2017 senesinden bu yana en düşük seviyesine 2020'nin Mayıs ayında ulaşmıştır. Rusya'yı da ciddi anlamda etkileyen Covid-19, MOEX Endeksi üzerinde 2020 Mart'ında meydana gelen düşüş ile birlikte 2019'un Mart ayından bu yana en düşük seviyesini görmüştür. Kolombiya'nın en önde gelen endeksleri arasındaki COLCAP Endeksi 2020 senesinde yaklaşık olarak toplamda \%35'lik bir düşüş ile Ekim 2020'de son 11 senenin en düşük seviyesine inmiştir.

Ülkemizde işlem görmekte olan ve piyasada hacimsel olarak en büyük paya sahip olan BIST100 endeksi ise, Mart 2017 tarihinden bu yana en düşük seviyesine Mart 2020'de inmiştir. Çeşitli ülkelerin öne çıan piyasa endekslerinde meydana gelen dalgalanmalardan da görüleceği gibi, bütün dünyayı etkileyen Covid-19 virüsünün küresel finansal piyasalarda da büyük bir kriz unsuru olduğunu söylemek mümkündür. 


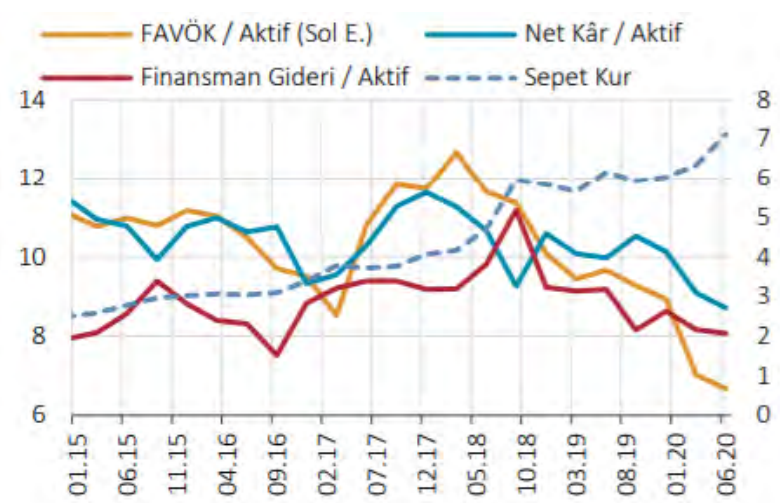

Şekil 2: BİST Firmaları Kârlılık Göstergeler

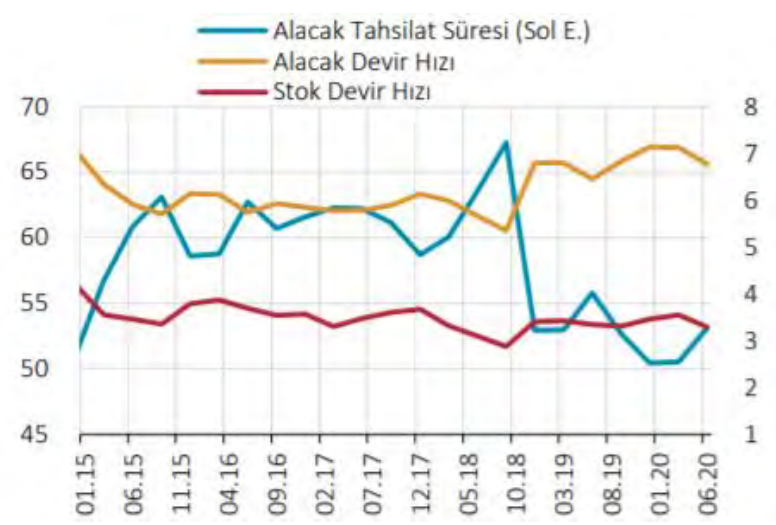

Şekil 3: Firmaların Faaliyet ve Likidite Göstergeleri

Şekil 2'de, BIST'te işlem görmekte olan işletmelerin faiz, amortisman ve vergi öncesindeki kârlılık durumları (FAVÖK) ve net kârlılıkları, salgın nedeniyle ilk olarak duraksayıp sonrasında güçlenen ihracat getirilerinin desteklemesine karşılık, salgın nedeniyle azalan iç talep ve yüksek girdi maliyetinden kaynaklanan fiyat baskıları ile 2020 yılının başlangıcından günümüze kadar düşüşünü sürdürmektedir. 2020 yılının Haziran ayı itibariyle BIST'te işlem görmekte olan işletmelerin FAVÖK/Aktif oranları \%7 seviyesinin altında seyrederken, Net Kar/Aktif oranları ise \%2,7 seviyesine gerilemiştir. İktisadi faaliyetlerde Mart-Mayıs dönemlerinde pandeminin etkileriyle ortaya çıan durağan durum, BIST işletmelerinin faaliyetlerine ve likidite oranlarına da yansımaktadır. Şekil 3'te görüleceği üzere, pandemi etkilerinin sektörlerin tamamında gözlenmesi ve etkilerin derinleşmesi ile beraber alacakların tahsil sürelerinin uzadığı ve 2020 yılının Haziran ayı itibariyle de 53 gün seviyelerine kadar çıktığı görülmektedir.

Küresel finansal piyasalar değişimlere duyarlı duruma gelmiştir ve bununla beraber küresel hisse senetlerinin endekslerinde de gerileme yaşanmıştır. Koronavirüsün yayılması hisse senedi fiyatlarında düşüşe sebep olurken fiyat oynaklığında artışa, nominal faiz oranında düşüşe ve reel ekonomik aktivitelerde daralmalara yol açarak reel GSYİH değerine yansımıştır (Kotishwar, 2020: 2). Özet olarak, Covid-19'un neden olduğu ekonomik kayıplar küresel borsaları derinden etkilemiştir. Finansal piyasalar başta olmak kaydıyla birtakım ülkelerin ekonomik ve finansal sisteminde sorunlara yol açan koronavirüsün yaygınlaşmasıyla birlikte küresel sağlık krizlerinin maliyeti artmıştır. Virüsün, bir bütün şeklinde borsalar üzerindeki uzun vadeli etkileri tam anlamıyla bilinmese de, borsalar bu süreçte spekülatif hareketlere maruz kalmıştır (Yan vd. 2020: 1).

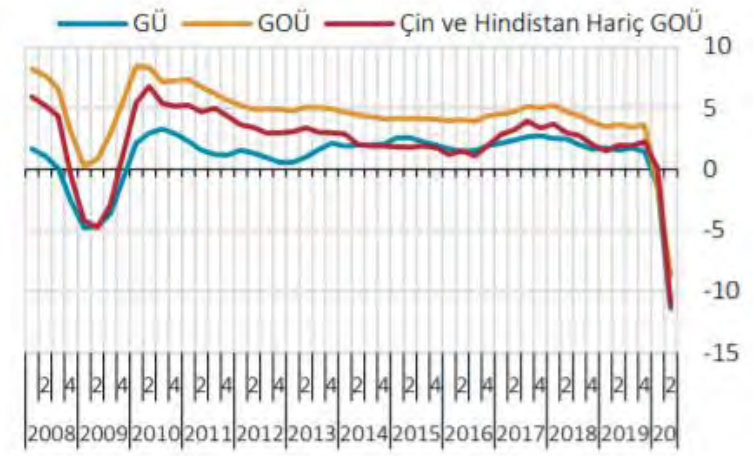

Şekil 4: GÜ ve GOÜ’lerde Yıllık Büyüme Oranları (\%)

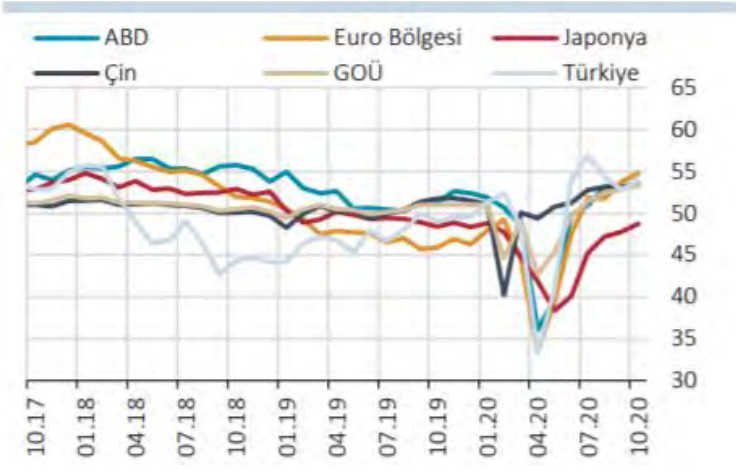

Şekil 5: İmalat Sanayi PMI (Endeks)

Şekil 4 ve Şekil 5'den görüleceği üzere, 2020 senesinin ilk yarısında, salgın ve karantina önlemlerinin negatif etkileri ile birlikte küresel finansal faaliyetler kritik seviyede azalmıştır. Büyümeye yönelik öncül göstergelere göre, 2020 yılının Mayıs ve Haziran aylarında karantina tedbirlerinin azaltılması ile başlayan küresel finansal faaliyetlerdeki toparlanma yöneliminin üçüncü çeyreğin sonunda da devam ettiği gözlenmiştir.

Koronavirüsün ekonomik faaliyetler üzerindeki etkisi Nisan 2020 itibariyle derinleşmiştir. Salgın kimi sektörlerde yavaşlamaya, kimi sektörlerde ise durma noktasına gelinmesine yol açmıştır. Söz konusu durum reel sektör üzerindeki baskıyı artırmış ve ekonomide ihtiyati likidite talebinin artmasına yol açmıştır. Pek çok ülkede olduğu şekilde Türkiye'de de politikacılar tarafından virüsün etkilerinin minimum seviyelere 


\section{A. Ertuğrul Ayranc1 - G. Arı 13/4 (2021) 3770-3785}

indirilebilmesi ve olumsuz yansımalarının önüne geçilebilmesi açısından geniş kapsamda bir politika ortaya konulmuştur (Finansal İstikrar Raporu, 2020: 32).

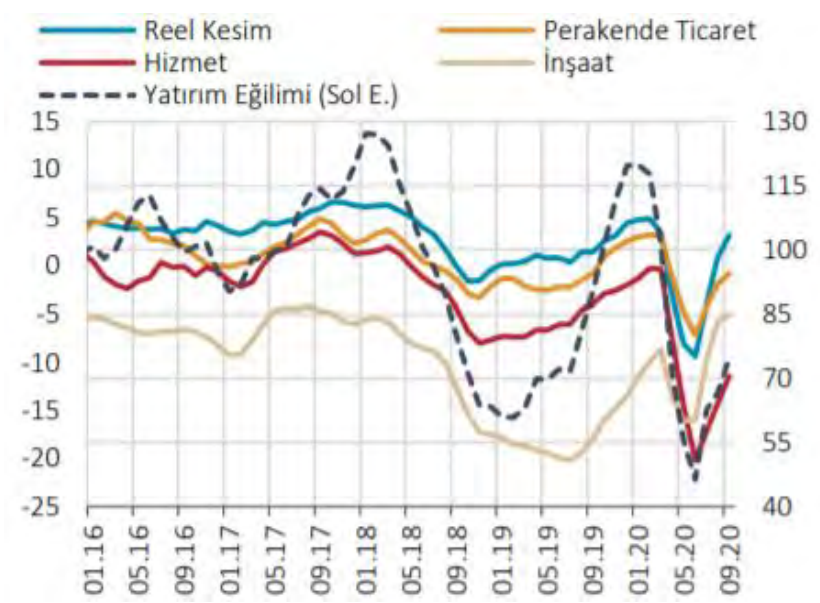

Şekil 6: Reel Sektör Güven Endeksleri ve Yatırım Eğilimi (Mevsimsellikten Arındırılmış)

Şekil 6, koronavirüs salgınının Mart 2020'den bu yana getirdiği ekonomik durgunluk ile birlikte ekonomik aktivitenin zayıflaması sonucu yaşanan keskin düşüşü göstermektedir. Salgın önlemlerinin kademeli olarak azaltılması ve salgın süresince uygulanan önlem ve politika adımları ile yılın üçüncü çeyreğinde güçlü bir toparlanma eğilimine girilmiştir. Salgının getirmiş olduğu sosyal izolasyon ve kişilerin temkinli seyahat kısıtlama seçimleri, turizm ile ilgili seyahat acentaları, konaklama, ulaşım ve restoranlar şeklindeki turizm ve hizmet sektörü alt gruplarını olumsuz yönde etkilemeyi sürdürmektedir. Önümüzdeki on iki ayı yansıtan imalat sanayindeki yatırım eğilimi, salgının belirsizlik etkileri nedeniyle Temmuz 2020'ye değin önemli ölçüde azalmıştır. Kamu teşviklerinin etkisi ve finansal şartlardaki gevşeme ile üçüncü çeyrekte azalan belirsizlikler ve ekonomideki toparlanma eğilimi Temmuz ayında yatırım trendinin yükselmeye başlamasına neden olmuştur. Bu dönemde yatırımların yükselen trendinde ihracatçı sektörlerin yarattığı talebin büyük etkisi bulunmaktadır.

Öte yandan 2008 Mali Krizi ile Covid-19 krizinin ortak yönleri olsa da çarpıcı farklılıklarının da bulunduğunu söylemek mümkündür. Öncelikle, gelişmekte olan ülkelerin büyüme eğilimleri 2007-2008 krizinde de devam etmiş ve krizden kaçan sermayelere sığınak olmayı başarmışlardır. Ancak mevcut krizde sermaye akışında, yüksek belirsizlik ve yüksek piyasa oynaklığı nedeniyle gelişmekte olan ülkelerden ziyade ABD gibi "güvenli limanlar" tercih edilmektedir (Kotishwar, 2020: 3). İkincisi; Covid-19 krizinde uygulanan karantina yaptırımları, tedarik zincirlerinin kopması ve iş yerlerinin kapanması nedeniyle hem arz hem de talebin yetersiz kalması, tek başına finansal genişlemeyle çözüm sağlanamayacak bir durumu ortaya çıkarmıştır (Fernandes, 2020: 10). Üçüncüsü, Nouriel Roubini'ye göre, hem 1929 yılında yaşanan kriz hem de 2008 Mali krizinin üretim, borsa ve işsizlik üstündeki etkileri 2-3 yıl içinde ortaya çıkarken, Covid-19 krizinin etkisi şu ana dek eşine rastlanmamış bir hızla hissedilmiştir (Rogoff, 2020: 2).

Merkezi yönetimlerin Covid-19 için aldığı önlemler, iki olası ana kanal aracıllğıyla borsa getirlerini etkileyebilmektedir. Birinci kanal olan rasyonel kanal, portföylerin yeniden yapılandırmasıyla ilişkilidir. Merkezi yönetim önlemleri, gelecekteki ekonomik koşul değişimine işaret etmekte, bu sebeple şirketlerin nakit akışı beklentilerini ve dolayısıyla hisse senedi fiyatlarını etkileyen olaylar meydana gelebilmektedir. Ani portföy yapılandırmaları, hem bir varlık sınıfını hem de varlık sınıfları arasında fiyat oynaklığını artırabilmektedir. İkinci kanal olan irrasyonel kanal, davranışsal nitelikte ortaya çıabilmektedir. Ekonomik ortamdaki bozulma, güvenli yatırım araçları olan hazine bonosu ve tahvillere kaçışa yol açabilmektedir (Lahmiri \& Bekiros, 2020: 4). Önemli olaylar, borsa getirileri üzerinde kritik ölçüde değişikliğe sebep olduğu için, gelişmekte olan ülkelerden biri olan Türkiye ve diğer dünya ülkeleri, yeni covid-19 salgını isimli ciddi bir şokla karşı karşıya kalmaktadır.

Yatırımcıların duygu ve hisleri, borsaları önemli şekilde etkilemektedir. Piyasalar yükseliş trendinde olduğu ve algılanan riskin daha az olduğu durumlarda, yatırımcılar genellikle daha iyimser davranmaktadırlar. Diğer yandan piyasalar düşüş trendindeyken, yatırımcıların hissiyatı görece karamsar duruma gelmektedir ve yatırımcılar, bir toparlanma başlayana dek piyasaya giriş yapmak üzere bekleme eğilimi göstermektedirler. 


\section{A. Ertuğrul Ayranc1 - G. Arı 13/4 (2021) 3770-3785}

$\mathrm{Bu}$ gibi durumlar kısa vadeli yatırımcıların aşırı tepki vermesine neden olmaktadır (Waheed, 2020: 1). Küreselleşme, dünyadaki ekonomileri birbirine bağlamıştır ve son dönemlerde küresel finansal piyasaların birbirine bağımlı bir hale gelmesini sağlamıştır. Küresel hisse senedi piyasalarının arasında bulunan söz konusu bağımlılık, ekonomik politikaların ve küresel yatırımcıların varlık tahsisi ve ekonomik kararları üstünde kritik düzeyde etkili olmaktadır (Liu, 2020: 2).

\subsection{Literatür Taraması}

Covid-19 virüsünün hızlı yayılımı ile ortaya çıkan pandemi, bütün dünyanın ekonomik yapısını ve finansal piyasaların hareketlerini doğrudan etkilemiştir. Pandemi durumunun meydana gelmesinden günümüze kadar akademisyenler tarafından bu salgınının piyasalar üzerindeki etkileri araştırılmaktadır.

Zhang ve diğerleri (2020) tarafınca gerçekleştirilen analiz çalışmasında, borsaların haftalık getirileriyle Covid19 vaka sayıları arasında bulunan ilişkiler 12 ülke için analiz edilmiştir. Çalışmanın sonucunda, borsadan elde edilen getiriler ile Covid-19 pandemisinin arasında bulunan korelasyonun kritik seviyede yükseldiği ortaya konulmuştur. Bununla beraber bu araştırmada, borsanın tepkilerinin söz konusu ülkede bulunan Covid-19 vaka sayısının yüksek olması ile doğrudan ilişkili olduğuna ulaşılmıştır.

Al-Awadhi ve diğerleri (2020), Çin borsasında işlem görmekte olan endeksler (Hang Seng Endeksi - Şanghay Menkul Kıymetler Borsası Kompozit Endeksi) ile Covid-19 vakaları ve ölümlerinden elde edilen sayısal verilerden faydalanarak hisse senedi getirilerindeki değişimi panel regresyon yöntemiyle analiz etmişlerdir. 10 Ocak- 16 Mart 2020 dönemine ilişkin verilerin kullanılmasıyla gerçekleştirilen analizin neticesinde, hisse senedi getirilerinin, gerek vakalardaki günlük artış gerekse Covid-19 virüsünün yol açtığ1 toplam ölüm sayılarındaki gündelik artış ile kritik seviyede negatif yönlü ilişkisi içinde olduğu tespit edilmiştir.

Onali (2020) tarafından yapılan çalışmada, Covid-19 salgınının ABD'deki hisse senedi getirileri (Dow Jones ve S\&P500 getirileri) ile dalgalanmalarının üstündeki etkilerini incelemek üzere 8 Nisan 2019-9 Nisan 2020'ye dek gerçekleşen veriler üzerinde GARCH $(1,1)$ modeli uygulanmıştır. 2020 senesinin Ocak, Şubat ve Mart aylarında ABD ve Covid-19 salgınından önemli seviyede pay alan öteki ülkelerin doğrulanmış vakalar ve ölüm sayılarındaki değişimlerin (Çin, İran, İtalya, Fransa, , İspanya ve Birleşik Krallık), Çin için raporlanan vaka sayısının (gündeliklerde) haricinde $\mathrm{ABD}$ hisse senedi getirilerinin üstünde etkisinin bulunmadığı tespit edilmiştir. VAR modelleri yardımıyla ise İtalya ve Fransa'da raporlanan ölüm sayılarının Dow Jones getirilerinin üstünde negatif yönlü bir etkisinin bulunduğu ve VIX üstünde pozitif yönlü bir etkisinin bulunduğu ortaya konulmuştur. Bunların yanı sıra, Markov-Switching modelleri, Şubat ayının sonlarında VIX'in hisse senedi getirilerinin üstündeki negatif yönlü etkisinin büyüklügünün üç kat daha artış gösterdiğine işaret etmiştir.

Alber (2020) tarafından yapılan çalışmada, Covid-19 vakalarının ve ölüm sayılarının borsa getirileri üzerinde etkisinin bulunup bulunmadığı araştırılmıştır. Veri seti, 1 Mart 2020 - 10 Nisan 2020 tarihleri arasındaki toplam vaka sayılarının en çok olduğu altı ülkenin özelinde (Çin, Fransa, Almanya, İtalya, İspanya, ABD) ele alınmıştır. Çalışmanın sonuçlarına göre borsadan elde edilen getirilerdeki azalmaların Covid-19 vaka sayılarına nispeten ölüm sayılarına daha duyarlı olduğu ortaya konulmuştur. Covid-19 virüsünün, borsa getirileri üstündeki negatif yönlü etkileri sadece Çin, Fransa, Almanya ve İspanya özelinde ispat edilmiştir.

Ashraf (2020) tarafından yapılan çalışmada hisse senetlerinin Covid-19 salgınına gösterdikleri tepkiler ele alınmıştır ve 22.01.2020 tarihinden 17.04. 2020 tarihine kadar geçen sürede 64 ülkenin hisse senedi getirileriyle, günlük doğrulanmış Covid-19 vakaları ve ölüm oranları kullanılmıştır. Araştırmada, hisse senetlerinin Covid19 olarak onaylanmış vakalardaki büyümeye negatif yönlü tepkiler gösterdiği, diğer bir ifadeyle doğrulanan vakalar yükseldikçe hisse senedi gelirlerinin azaldığı bulgusu ortaya konulmuştur.

Chaouachi ve Chaouachi (2020) tarafından yapılan çalışmada Covid-19 virüsünün KSA borsasının üstündeki etkileri ARDL modelinden yararlanılarak 02 Mart-20 Mayıs 2020 zaman dilimindeki günlük veriler ile analiz edilmiştir. Bununla beraber değişkenlerin arasında yer alan nedensellik ilişkisi Toda- Yamamoto nedensellik analizinden yararlanılarak analiz edilmiştir. Çalışmanın neticesinde, Covid-19'un borsanın üzerinde yalnızca uzun vadeli olarak negatif yönlü etkisinin bulunduğu tespit edilmiştir. Bunun yanı sıra nedensellik testinin neticesinde Covid-19'dan hisse senedi piyasalarına doğru tek taraflı nedensellik ilişkisinin bulunduğu belirlenmiştir. 


\section{A. Ertuğrul Ayranc1 - G. Arı 13/4 (2021) 3770-3785}

Ahmed (2020) tarafından COVID-19 virüsünün Pakistan'daki borsa performansının üstündeki etkilerini tespit etmek üzere yapılan çalışmada, yalnızca Covid-19 olduktan sonra iyileşen hastaların endeksi olumlu yönde etkilediği tespit edilmiştir. Bununla beraber doğrulanmış Covid-19 vakalarının ve ölüm sayılarının borsa performansına etkilerinin göz ardı edilebilecek seviyede olduğu belirlenmiştir.

Waheed ve diğerleri (2020) tarafından Covid-19 virüsünün gelişmekte olan bir pazar olarak bilinen Pakistan borsasının üstündeki etkilerinin incelendiği çalışmada, KSE-100 endeksinin borsa getirileri üzerinde olumlu yönde bir artışı sağladığı tespit edilmiştir.

Kotishwar (2020) tarafından Covid-19 salgınının borsaların üstündeki etkilerini belirlemek üzere, 11 Marttan Nisan 2020 arasındaki süreçte virüsten en olumsuz şekilde etkilenen 6 ülkedeki (ABD, İspanya, Fransa, İtalya, Çin ve Hindistan) doğrulanmış vakaların artışını kullanarak yapılan çalışmada VECM modelinden faydalanılmıştır. Çalışmanın sonuçlarına göre, Covid-19'un ele alınan bütün ülkelerdeki borsa endeksleri ile kritik seviyede olumsuz yönde ve uzun vadede iişkili bulunduğu ortaya konulmuştur.

He ve diğerleri (2020) tarafınca yapılan ve Covid-19 virüsünün pay senetleri üstündeki doğrudan etkilerinin ve yayılmalarının ele alındığı çalışmada, geleneksel t-testleri ve non-parametrik Mann-Whitney testlerinden yararlanılarak, Çin Halk Cumhuriyeti, Japonya, Güney Kore, Fransa, İtalya, Almanya, İspanya ve ABD'deki borsaların günlük getirilerinin verileri incelenmiştir. Araştırmanın sonucunda, Covid-19'dan olumsuz olarak etkilenmiş olan bütün ülkelerin borsalarının üstünde pandeminin negatif yönlü fakat kısa vadeli bir etkisinin bulunduğu ve Covid-19'un borsa performansı üstündeki etkilerinin Avrupa, Amerika ve Asya ülkeleri arasında iki taraflı yayılma etkilerinin bulunduğu ortaya konulmuştur.

Sansa (2020) tarafından Covid-19 virüsünün Çin ve ABD'deki mali piyasalar üstündeki etkileri, 1 ile 25 Mart tarihleri arasında gerçekleşen verilerle basit regresyon modelinden faydalanılarak analiz edilmiştir. Çalışmanın neticesinde Covid-19 salgınıyla seçilen ülkelerin finansal piyasalarının arasında olumlu ve istatistiksel olarak anlamlı bir ilişkinin bulunduğu belirlenmiştir.

Liu ve diğerleri (2020) Almanya, Singapur, ABD, Japonya, Kore İtalya ve İngiltere'nin de içinde bulunduğu ve Covid-19 virüsünden olumsuz olarak etkilenmiş ülkelerin, pandeminin hisse senedi endekslerinin üstündeki kısa vadeli etkilerini ele almışlardır. Çalışmanın sonucunda salgından etkilenen ülke ve bölgelerde işlem gören hisse senetlerinin virüs salgınının sonrasında hızlı bir şekilde düşüş yaşadığı tespit edilmiştir. Asya kıtasında bulunan ülkelerin, diğer ülkelere göre nispeten daha çok olumsuz anormal getiri yaşadıkları çalışmanın diğer bulguları arasındadır.

Morales ve Andreosso (2020) araştırmalarında, Covid-19'un SSE, CAC40, DAX30, FTSEMIB, NIKKEI225, IBEX35, FTSE100, S\&P500 ve NASDAQ gibi önde gelen borsalar üzerindeki etkilerini incelemişlerdir. Elde ettikleri sonuçlara göre, virüsün özellikle Avrupa ülkelerine de yayılmasıyla birlikte finansal belirsizliği meydana getirdiği ve borsalar üzerinde etkilere sebep olduğu belirtilmiştir.

Zeren ve Hızarcı (2020) tarafından yapılan çalışmada Covid-19 salgınından en fazla etkilenen ülkeler olan Fransa, İtalya, Güney Kore, Almanya, Çin, ve İspanya'da 23.01.2020 ve 13.03.2020 tarihlerinin arasında gerçekleşen kümülatif günlük vakalar ve ölümlerin sayıları ile Maki (2012) eşbütünleşme testinden faydalanılarak Covid-19 ile borsa getirileri arasındaki ilişki analiz edilmiştir. Covid-19 nedeni ile ölümler ve bütün borsaların uzun vadede beraber hareket ettikleri belirlenmiştir. Covid-19 kümülatif vaka sayıları ile IBEX35,KOSPI, SSE piyasaları arasında uzun dönemli bir ilişki olduğu tespit edilirken, MIB, DAX30, CAC40 ve FTSE piyasaları arasında ise uzun dönemli bir ilişkinin bulunmadığı ortaya konulmuştur.

Şenol ve Zeren (2020) tarafından salgının küresel ekonomiler üzerindeki etkisi, hisse senedi piyasaları bakımından ele alınmıştır. Araştırmada, Covid-19 vakaları ve ölüm sayılarından yararlanılarak Morgan Stanley Capital International (MSCI) Dünya Endeksleri, Avrupa, Yükselen Piyasalar ve G7 piyasalarının 21.01.2020 ile 7.01.2020 arasındaki döneme ilişkin veriler ile Fourier eşbütünleşme testleri yapılmıştır. Hisse senedi piyasalarıyla Covid-19 salgını arasında uzun dönemli bir ilişkinin bulunduğu belirlenmiştir.

Kandil Göker ve çalışma arkadaşları (2020) tarafınca ortaya konulan araştırmada, pandemi kapsamında BIST'te işlem görmekte olan 26 farklı endüstrinin 2 Ocak 2019 - 9 Nisan 2020 dönemlerine ilişkin verilerinden faydalanılarak olay çalışması yapılmıştır. Çalışmanın neticesinde, ele alınan olay dönemlerinin birçoğunda pek çok endüstrinin olumsuz Birikimli Ortalama Olağanüstü Getiri (CAAR) elde ettikleri, kimi dönemler için 


\section{A. Ertuğrul Ayranc1 - G. Arı 13/4 (2021) 3770-3785}

ise çeşitli sektörlerin CAAR değerlerinin olumlu yönde seyrettiği tespit edilmiştir. Çeşitli olaylara göre söz konusu oranların değişmesi ile beraber en büyük kaybın Spor, Turizm ve Taşımacılık endüstrilerinde yaşandı̆̆ belirlenmiştir.

Öztürk ve diğerleri (2020) tarafından yapılan araştırmada 2 Ocak 2020 ile 15 Nisan 2020 tarihlerinin arasında gerçekleşen verilerden faydalanılarak Covid-19 salgınının BİST'te işlem görmekte olan endüstriler üzerindeki etkileri ele alınmıştır. Çalışmanın neticesinde, Covid-19 virüsünün hemen hemen bütün sektörler üzerinde olumsuz etkisinin bulunduğu tespit edilmiştir. Ortalama olarak, 3 temel sektörün (sanayi, hizmet ve finans) aşağı yukarı eşit seviyede etkilendiği ve sektörler seviyesinde ise birtakım farklılıkların bulunduğu tespit edilmiştir. Daha çok ulaşım, turizm, spor, metal ürünleri, makine, bankacılık ve sigortacılık sektörlerinin, salgından en fazla etkilenmiş olan sektörler olduğunu söylemek mümkündür. Diğer taraftan; toptan ve perakende, gıda, ticaret sektörlerinin ise salgından daha az etkilenmiş olan sektörler olduğu ifade edilmiştir.

Tayar ve diğerleri (2020) tarafından yapılan çalışmada Covid-19 salgınının Türkiye'de faaliyet gösteren sektörler üzerindeki etkileri analiz edilmiştir. 17 Mart ile 28 Nisan 2020 arasında geçen döneme ilişkin Türkiye'de ortaya çıkan vakaların sayısındaki gündelik değişimler ve BİST sektörel endekslerinin gündelik değişimlerimden faydalanılarak basit doğrusal regresyon analizi uygulaması yapılmıştır. Analizin neticesinde, Covid-19 virüsünün elektrik, ulaştırma, finans, sanayi ve teknoloji sektörleri üzerinde etkilerinin bulunduğu tespit edilmiştir.

Kılıç (2020) tarafından yapılan çalışmada BİST sektör endekslerine yönelik 2 Ocak 2018 ile 30 Nisan 2020 döneminde gerçekleşen verilerden faydalanılarak, Covid-19 virüsünün sektörler üzerindeki etkileri olay etüdü yöntemi ile incelenmiştir. Çalışmanın neticesinde, Covid-19 virüsünün, BİST sektörel endeks getirilerinin üzerinde genel olarak negatif yönlü etkilerinin bulunduğu belirlenmiştir. En yüksek olumsuz etkinin ise tekstil ve turizm sektörlerinde gerçekleştiği tespit edilirken ticaret sektörünün ise pandemi boyunca olumlu getiriler sağladığı ortaya konulmuştur.

Topçu ve Gülal (2020) tarafından yapılan çalışmada, Covid-19 salgınının gelişmekte olan ülkelerin borsaları üzerindeki etkileri ele alınmıştır ve salgının, gelişmekte olan borsaların üzerindeki negatif yönlü etkilerinin kademeli şekilde azaldığı tespit edilmiştir. Bununla beraber Covid-19 etkilerinin en çok, yükselen Asya piyasalarında görüldüğü tespit edilmiştir.

Barut ve Kaygın (2020) çalışmalarında Bayer ve Hanck (2012) eşbütünleme analizi kullanarak çalışma tarihinde Covid-19 vaka sayısının en fazla olduğu 11 ülkenin borsa endeksini analiz etmişlerdir. Çalışmanın tarih aralığı olarak vakanın o ülkede ilk görüldüğü tarihten 08.04.2020'ye kadarki günlük kapanış verileri kullanılmıştır. Analizin neticesinde, Covid-19 toplam vaka sayıları ve BIST100, IBEX35, AEX, FTSE, MIB ve Shangai endeksleri arasında eşbütünleşme ilişkisinin olduğunu, FTSE 100, BEL 20, DAX, CAC 40, SMI ve DOW 30 endeksleri arasında ise eşbütünleşme ilişkisinin olmadığını belirlemişlerdir.

Gülhan (2020) çalışmasında, 31.12.2019- 28.05.2020 tarihleri arası günlük verileri kullanarak Covid-19 pandemisinin BIST100 üzerindeki kısa ve uzun dönem için etkilerini incelemiştir. Etkilenen değişken olarak BIST100 endeksi, bağımsız değişkenler olarak Covid-19 Türkiye ölüm oranları, US dolar kuru, enfeksiyon hastalıkları ile sermaye piyasaları oynaklık endekslerinden faydalanılmıştır. Kurulan modele göre, pandemi sürecinin seçilen kontrol değişkenleriyle birlikte BIST100 üzerinde gerek kısa vadede gerekse de uzun vadede etkili olduğu sonucuna ulaşmışladır.

\section{YÖNTEM}

\subsection{Araştırmanın Amacı ve Modeli}

Çalışmanın temel amacı küresel finansal piyasalarda şoklara neden olan Covid-19 salgınının Türkiye hisse senedi piyasaları üzerindeki etkisini araştırmaktır. İlgili amaç doğrultusunda araştırmada yapılacak analiz kapsamında, [13.03.2020 - 07.05.2021] haftanın 5 gününü içeren günlük veriler için covid vaka sayısı ve BISTT_banka, BİST_hizmet, BİST_sanayi, BİST_turizm ve BİST_ulaştırma endeksleri arasındaki ilişkiler uzun ve kısa dönem olarak ele alınmıştır. Çalışmanın hipotezi; covid vaka sayısı ve BİST alt endeksleri (bankacılık, hizmet, sanayi, turizm ve ulaştırma) arasında istatistiksel açıdan anlamlı ilişkili olduğu yönündedir.

Ekonometrik analiz, covid vaka sayısının BİST alt endekslerine olan etkisinin uzun ve kısa dönem ilişkisini kapsamaktadır. Buradan hareketle çalışmada 5 model analiz edilecektir: 
Model 1: BISTT_mali=f(covid)

Model 2: BİST_hizmet=f(covid)

Model 3: BiST_sanayi=f(covid)

Model 4: BİST_turizm=f(covid)

Model 5: BİST_ulast=f(covid)

\subsection{Veri Seti ve Yöntem}

13.03.2020 - 07.05.2021 dönem aralığı kapsamında haftanın 5 gününü içeren günlük veriler için BIST alt endekslerine ilişkin veriler www.reuters.org ve Covid-19 vaka sayılarına ilişkin verileri ise https://covid19.saglik.gov.tr/ veri bankasından elde edilmiştir. Analizlerin sonuçları, Eviews programı 10.0 sürümü ile STATA programı 15.0 sürümünden faydalanılarak elde edilmiştir. Modelde bulunan değişkenleri aşağıda sunulan Tablo 1'de görmek mümkündür.

Tablo 1: Analizlerde Değerlendirilen Değişkenler Tablosu

\begin{tabular}{lcc}
\hline Değişken & Gösterim & Tanım \\
\hline Covid vaka sayısı & COVID & Bağımsız değişken \\
\hline BİST Mali & BİST_MALI & Bağımlı değişken \\
\hline BİST Hizmet & BİST_HİZMET & Bağımlı değişken \\
\hline BİST Sanayi & BİST_SANAYİ & Bağımlı değişken \\
\hline Bi̇ST Turizm & BİST_TURIZM & Bağımlı değişken \\
\hline BİST Ulaştırma & BİST_ULAST & Bağımlı değişken \\
\hline
\end{tabular}

Değişkenlere ilişkin zaman serisi grafikleri Şekil 7'de ve verilere yönelik tanımsal bilgiler ise Tablo 2'de verilmiştir.
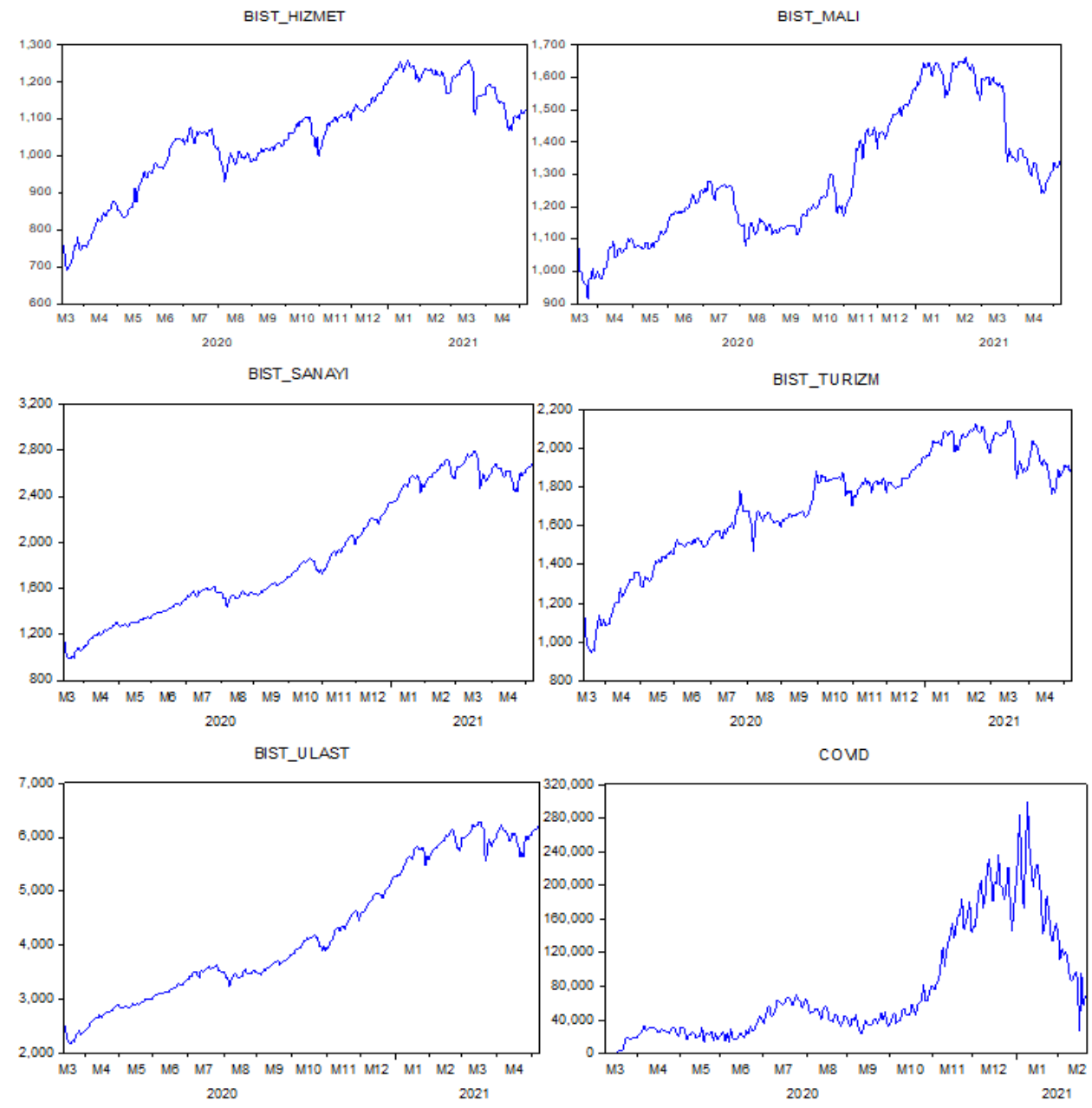

Şekil 7. Değişkenlere İlişkin Zaman Serisi Grafikleri 
A. Ertuğrul Ayranc1 - G. Arı 13/4 (2021) 3770-3785

Tablo 2: Verilere Yönelik Tanımsal Bilgiler

\begin{tabular}{lcccccc}
\hline İstatistikler & COVID & BIST_MALI & BIST_HIZMET & BIST_SANAYI & BIST_TURIZM BIST_ULAST \\
\hline Ortalama & 1190059 & 1290.936 & 1052.815 & 1889.985 & 1708.266 & 1267.669 \\
\hline Medyan & 332382 & 1245.150 & 1065.490 & 1751.010 & 1772.490 & 1944.030 \\
\hline Maksimum & 4998089 & 1663.710 & 1259.450 & 2793.580 & 2145.380 & 2297.950 \\
\hline Minimum & 5 & 914.0200 & 691.5300 & 988.3700 & 942.6000 & 989.240 \\
\hline St.sapma & 1401067 & 196.8429 & 137.6031 & 538.7318 & 282.3813 & 1244.876 \\
\hline
\end{tabular}

Çalışmada kullanılan verilerin durağanlıklarını test etmek üzere Augmented Dickey-Fuller (ADF) ve PhillipsPerron (PP) testlerinden faydalanılmıştır. Denklem sistemindeki değişkenlerin ortak gecikme uzunluklarının belirlenmesi açısından alanyazında çoğunlukla faydalanılan birtakım ölçütler bulunmaktadır. Söz konusu ölçütler; Final Prediction Error (FPE), Hannan-Quinn (HQ), Schwarz (SW), Likelihood Ratio (LR) ve Akaike Information Criteria (AIC) olarak sıralanabilir. Bahsi geçen ölçütlerden yola çıkılarak verilerin gecikme uzunlukları tespit edilmiştir. Uzun dönemli ilişkilerin belirlenebilmesi için Bayer-Hanck (2013) Eşbütünleşme Analizi'nden faydalanılmıştır. Kısa dönemli ilişkilerin belirlenebilmesi için ise hata düzeltme modelinden yararlanılmıştır.

\subsubsection{Bayer - Hanck (2013) Eşbütünleşme Analizi}

Uzun dönemli regresyon modelinin artıklarına dayalı olarak tahmin edilen Engle-Granger (1987) eşbütünleşme testi, birim kök içeren serileri durağan duruma getirmeden seriler arasındaki uzun dönemli ilişkinin belirlenmesini sağlamaktadır. Fakat Engle-Granger eşbütünleşme testinin birden çok açıklayıcı değişkene sahip modeller için birtakım zayıf yönlerinin bulunduğu görüşü kabul edilmektedir (Govindaraju ve Tang, 2013: 314). Daha sonrasında Johansen (1991) tarafından geliştirilen eşbütünleşme testi ise gecikme uzunluğuna son derece duyarlı bir test olarak karşımıza çıkmaktadır (Kızılgöl, 2006: 58). İlerleyen dönemlerde Boswijk (1994) hata düzeltme modeline dayalı yeni bir eşbütünleşme testi sunmuş ve bunu F istatistiği ile uygulamıştır. Banerjee ve diğerleri (1998) testi, hata düzeltme modeline ve $t$ istatistiğine dayanmaktadır. Yukarıda bahsedilen eşbütünleşme testlerinin hiçbiri mükemmel veya tamamen güçlü testler olarak kabul edilmemektedir. Literatürdeki eşbütünleşme testlerinin çelişkili sonuçlarına dayanarak Bayer ve Hanck (2013), Engle ve Granger (1987), Johansen (1991), Boswijk (1994) ve Banerjee ve diğerleri. (1998) testlerini beraber olacak şekilde değerlendirmeye alan yeni bir eşbütünleşme testi geliştirmişlerdir. Bu testlerin olasılık değerlerini (anlamlılık seviyelerini) bütünleştiren ve daha güçlü bir test elde eden Bayer ve Hanck (2013) eşbütünleşme testinde; Engle-Granger (1987) tek denklem, Johan-sen (1991) çoklu denklem testi, Boswijk (1994) hata düzeltme terimi ve Banerjee et al. (1998)'in testleri olasılık değerleri dikkate alınarak yapılmaktadır (Shahbaz, vd. 2013: 10, Aktürk, vd. 2014: 122). Bayer-Hanck (2013) eşbütünleşme testi, Fisher'in ki-kare dağılım formülü izlenerek bireysel olasılık değerlerini bir araya getirmiştir (Arı, 2016: 61):

$$
\begin{aligned}
& E G-J O H=-2\left[\ln \left(P_{E G}\right)+\ln \left(P_{J O H}\right)\right] \\
& E G-J O H-B O-B D M=-2\left[\ln \left(P_{E G}\right)+\ln \left(P_{J O H}\right)+\ln \left(P_{B O}\right)+\ln \left(P_{B D M}\right)\right]
\end{aligned}
$$

Denklem (1) ve Denklem (2)'de bulunan PЕG, Рرон, Рво, РвDм, Engle-Granger (1987), Johansen (1991), Boswijk (1994) ve Banerjee ve diğerlerinin (1998) eşbütünleşme testlerinin olasılık değerlerine işaret etmektedir. Hesap edilen test istatistiği Bayer-Hanck (2013) tarafınca ortaya konulan kritik seviyeden büyük ise, eşbütünleşme ilişkisinin bulunmadığına yönelik kurulan ana hipotez reddedilir ve seriler arasında eşbütünleşme ilişkisi bulunduğuna karar verilmektedir.

\section{BULGULAR}

Birinci aşamada, verilerin durağanlıklarını belirlemek üzere testler yapılmıştır. Yapılan bütün testlerde "sabit" veya "sabit + trend" tercihi yapılmıştır. Mevsimsellik etkilerinin giderilmesi amacıyla değişkenlerin logaritmaları alınmıştır. 
A. Ertuğrul Ayranc1 - G. Arı 13/4 (2021) 3770-3785

Tablo 3: Değişkenler İçin Uygulanan ADF ve PP Birim Kök Testlerinin Sonuçları

\begin{tabular}{|c|c|c|c|c|}
\hline \multirow{2}{*}{ Değişkenler } & \multicolumn{2}{|c|}{ ADF } & \multicolumn{2}{|c|}{ PP } \\
\hline & Sabit & Sabit+trend & Sabit & Sabit+trend \\
\hline LogCOVID & $-0.821(0.118)$ & $-0.933(0.128)$ & $-0.946(0.135)$ & $-1.213(0.138)$ \\
\hline LogBİST_MALI & $-1.256(0.122)$ & $-1.301(0.134)$ & $-1.298(0.116)$ & $-1.364(0.127)$ \\
\hline LogBİST_HİZMET & $-1.133(0.129)$ & $-1.242(0.133)$ & $-1.137(0.136)$ & $-1.288(0.138)$ \\
\hline LogBİST_SANAYİ & $-1.163(0.109)$ & $-1.167(0.142)$ & $-1.185(0.152)$ & $-1.211(0.163)$ \\
\hline LogBİST_TURİZM & $-1.213(0.165)$ & $-1.186(0.120)$ & $-1.231(0.130)$ & $-1.354(0.140)$ \\
\hline LogBİST_ULAST & $-1.184(0.128)$ & $-1.237(0.131)$ & $-1.174(0.147)$ & $-1.308(0.353)$ \\
\hline$\Delta$ LogCOVID & $-7.953(0.000)^{*}$ & $-8.125(0.000)^{*}$ & $-7.743(0.000)^{*}$ & $-7.993(0.000)^{*}$ \\
\hline$\Delta$ LogBİST_MALİ & $-8.613(0.000)^{*}$ & $-8.916(0.000)^{*}$ & $-8.803(0.000)^{*}$ & $-8.982(0.007)^{*}$ \\
\hline$\Delta$ LogBİST_HİZMET & $-8.569(0.000)^{*}$ & $-9.133(0.000)^{*}$ & $-8.734(0.000)^{*}$ & $-9.241(0.000)^{*}$ \\
\hline LLogBİST_SANAYİ & $-8.326(0.005)^{*}$ & $-8.734(0.009)^{*}$ & $-8.513(0.004)^{*}$ & $-8.910(0.000)^{*}$ \\
\hline$\Delta$ LogBİST_TURIZM & $-7.886(0.001)^{*}$ & $-8.452(0.003)^{*}$ & $-8.106(0.009)^{*}$ & $-8.355(0.000)^{*}$ \\
\hline$\Delta$ LogBİST_ULAST & $-8.447(0.000)^{*}$ & $-8.770(0.000)^{*}$ & $-8.311(0.000)^{*}$ & $-8.782(0.016)^{*}$ \\
\hline
\end{tabular}

${ }^{*} 0,05$ için dură̆an değ işken.

Not: parantez içi değerler (p) değerleridir ve $\Delta$ gösterimi birinci mertebe farkı belirtmektedir.

Tablo 3'te sunulan çıktılar doğrultusunda, değişkenlerin tamamının birim köke sahip olduğu görülmektedir. Değişkenlerin birinci seviye farkları alındığında durağanlık elde edilmiştir ve buna göre I(1) düzeyinde durağan olduğunu söylemek mümkündür. Eşbütünleşme analizinde gecikmelerin uzunlukları tespit edilmiştir.

Tablo 4: Değişkenlerin Gecikme Seviyelerinin Belirlenmesi İçin Kullanılan Kriterler

\begin{tabular}{llllll}
\hline & LR & FPE & AIC & SC & HQ \\
\hline Model 1 & 1 gecikme & 1 gecikme & 1 gecikme & 2 gecikme & 1 gecikme \\
\hline Model 2 & 1 gecikme & 2 gecikme & 1 gecikme & 1 gecikme & 1 gecikme \\
\hline Model 3 & 2 gecikme & 1 gecikme & 1 gecikme & 1 gecikme & 2 gecikme \\
\hline Model 4 & 2 gecikme & 1 gecikme & 1 gecikme & 2 gecikme & 1 gecikme \\
\hline Model 5 & 2 gecikme & 2 gecikme & 1 gecikme & 1 gecikme & 1 gecikme \\
\hline
\end{tabular}

Tablo 4'te görüleceği üzere, beş model için çoğunluk kriter 1 gecikme açısından uygunluk göstermektedir. Buna göre, eşbütünleşme analizleri, ele alınan değişkenlerin birinci seviyedeki farkları ile 1 gecikme uzunlukları kullanılarak gerçekleştirilecektir. Bayer-Hanck eşbütünleşme testinin sonuçlarını Tablo 5'te görmek mümkündür.

Tablo 5: Bayer-Hanck (2013) Eşbütünleşme Testi Sonuçları

\begin{tabular}{|c|c|c|c|}
\hline Modeller & EG-JOH & EG-JOH-BO-BDM & Eşbütünleşme \\
\hline Model 1: & 7.685 & 8.453 & Yok \\
\hline \multicolumn{4}{|l|}{ FLogBIST_mali $=f($ FLogcovid $)$} \\
\hline Model 2: & $15.225^{*}$ & $24.372^{* *}$ & Var \\
\hline \multicolumn{4}{|l|}{ FlogBIST_hizmet $=f($ FLogcovid $)$} \\
\hline Model 3: & $18.390^{*}$ & $28.341^{*}$ & Var \\
\hline \multicolumn{4}{|l|}{ FLogBIST_sanayi $=f($ FLogcovid $)$} \\
\hline Model 4: & $19.844^{*}$ & $29.502^{*}$ & Var \\
\hline \multicolumn{4}{|l|}{ FLogBIST_turizm $=f($ FLogcovid $)$} \\
\hline Model 5: & $18.399^{* *}$ & $26.918^{*}$ & Var \\
\hline FLogBIST_ulast $=f($ FLogcovid $)$ & & & \\
\hline
\end{tabular}


A. Ertuğrul Ayranc1 - G. Arı 13/4 (2021) 3770-3785

Bayer ve Hanck (2013) eşbütünleşme testinin çıktıları ele alındığında, Bist-mali endeksi dışında kalan hizmet, sanayi, turizm ve ulaştırma endeksleri için hesaplanan iki Fisher Test istatistiği değeri bütün endeksler için kritik değerden büyük olduğundan covid vaka sayısı ile aralarında eşbütünleşme ilişkisinin olduğu tespit edilmiştir. Böylece, covid sayısı ve belirtilen endeksler arasında uzun dönemli bir ilişkinin bulunduğu belirlenmiştir. Diğer yandan Bist-mali endeksi için uzun dönemli bir ilişki bulunmadığı tespit edilmiştir. Eşbütünleşme ilişkisi ortaya konulan dört model açısından uzun dönem eşbütünleşme katsayısı tahminleri Tam Değiştirilmiş Sıradan En Küçük Kareler: FMOLS yöntemi kullanılarak yapılmıştır.

Tablo 6: FMOLS Uzun Dönem Eşbütünleşme Katsayı Tahminleri

\begin{tabular}{|c|c|}
\hline Modeller & F(LogCOVID) \\
\hline Model 2: & $-0.052^{*}$ \\
\hline \multicolumn{2}{|l|}{ FLogBÍST_hizmet $=f($ FLogcovid $)$} \\
\hline Model 3: & $-0.063^{*}$ \\
\hline \multicolumn{2}{|l|}{ FLogBÍsT_sanayi $=f($ FLogcovid $)$} \\
\hline Model 4: & $-0.054^{*}$ \\
\hline \multicolumn{2}{|l|}{ FLogBÍST_turizm $=f($ FLogcovid $)$} \\
\hline Model 5: & $-0.047^{*}$ \\
\hline FLogBísT_ulast $=f($ FLogcovid $)$ & \\
\hline
\end{tabular}

FMOLS yöntemi analiz edilirken otokorelasyon ve değişen varyans problemleri Newey-West yönteminden yararlanılrak çözülmeye çalışılmıştır. Varsayım testlerinin neticesinde herhangi bir varsayımsal sapma gözlemlenmemiştir. Tablo 6'ya göre; covid vaka sayısı BIST__hizmet endeksini \%5.2 azaltmakta, BİST_sanayi endeksini \%6.3 azaltmakta, BIST_turizm endeksini \%5.4 azaltmakta ve BİST_ulast endeksini \%4.7 azaltmaktadır. Covid vaka sayılarının diğer endekslere göre en çok sanayi endeksini olumsuz etkilediği görülmüştür.

Hata düzeltme modeli (Vektör Hata Düzeltme Modeli: VECM), uzun dönemde beraber hareket etmekte olan değişkenlerin kısa dönemli dinamiklerini tespit etmek için tahminlenmiştir. Söz konusu tahminin neticesinde ulaşılan bilgileri aşağıda verilen Tablo 7'de görmek mümkündür:

Tablo 7: Kısa Dönem Hata Düzeltme Modeli Tahmin Sonuçları

\begin{tabular}{|c|c|c|}
\hline Model 1: Bağımlı Değişken: $\Delta$ LBİST_MALİt & Katsayı & Diagnostik testler \\
\hline$\triangle \mathrm{LCOVID}_{\mathrm{t}}$ & -0.021 & $R^{2}=0.256$, Adj. $R^{2}=0.245 \quad F(p)=0.231^{*}$ \\
\hline $\mathrm{ECT}_{\mathrm{t}-1}$ & -0.273 & Breusch-Godfrey LM Test $(p)=0.093^{*}$ \\
\hline Sabit & 2.784 & $\begin{array}{l}\text { White Test }(p)=0.15^{*}, \text { Ramsey RESET Test } \\
(p)=0.034, \text { JB test }(p)=0.035\end{array}$ \\
\hline $\begin{array}{l}\text { Model 2: Bağımlı Değişken: } \\
\Delta \text { LBİST_HİZMET }_{t}\end{array}$ & Katsayı & Diagnostik testler \\
\hline$\Delta \mathrm{LCOVID}_{\mathrm{t}}$ & $-0.078^{*}$ & $R^{2}=0.677$, Adj. $R^{2}=0.672, F(p)=0.000^{*}$ \\
\hline $\mathrm{ECT}_{\mathrm{t}-1}$ & $-0.386^{*}$ & Breusch-Godfrey LM Test $(p)=0.121^{*}$ \\
\hline Sabit & $1.372^{*}$ & $\begin{array}{l}\text { White Test }(p)=0.119^{*}, \text { Ramsey RESET Test } \\
(p)=0.145^{*} \text {, JB test }(p)=0.236\end{array}$ \\
\hline $\begin{array}{l}\text { Model 3:Bağımlı Değişken: } \\
\Delta \text { LBİST_SANAYİ }\end{array}$ & Katsayı & Diagnostik testler \\
\hline$\Delta \mathrm{LCOVIDt}_{\mathrm{t}}$ & $-0.092^{*}$ & $R^{2}=0.682$, Adj. $R^{2}=0.681, F(p)=0.000^{*}$ \\
\hline $\mathrm{ECT}_{\mathrm{t}-1}$ & $-0.406^{*}$ & Breusch-Godfrey LM Test $(p)=0.114^{*}$, \\
\hline Sabit & $1.581^{*}$ & $\begin{array}{l}\text { White Test }(p)=0.137^{*}, \text { Ramsey RESET Test } \\
(p)=0.106^{*} \text {, JB test }(p)=0.241\end{array}$ \\
\hline
\end{tabular}




\begin{tabular}{|c|c|c|}
\hline $\begin{array}{l}\text { Model 4:Bağımlı Değişken: } \\
\Delta \text { LBİST_TURİZMt }\end{array}$ & Katsayı & Diagnostik testler \\
\hline$\Delta \mathrm{LCOVID}_{\mathrm{t}}$ & $-0.062^{*}$ & \multirow{4}{*}{$\begin{array}{l}R^{2}=0.623, \text { Adj. } R^{2}=0.621, F(p)=0.000^{*}, \\
\text { Breusch-Godfrey LM Test }(p)=0.134^{*}, \\
\text { White Test }(p)=0.143^{*}, \text { Ramsey RESET Test } \\
(p)=0.167^{*}, \text { JB test }(p)=0.311\end{array}$} \\
\hline $\mathrm{ECT}_{\mathrm{t}-1}$ & $-0.375^{*}$ & \\
\hline \multirow[t]{2}{*}{ Sabit } & & \\
\hline & $2.138^{*}$ & \\
\hline Model 5:Bağımlı Değişken: $\Delta$ LBİST_ULAST & Katsayı & Diagnostik testler \\
\hline$\Delta \mathrm{LCOVIDt}_{\mathrm{t}}$ & $-0.059^{*}$ & \multirow{3}{*}{$\begin{array}{l}R^{2}=0.656, \text { Adj. } R^{2}=0.655, \quad F(p)=0.000^{*}, \\
\text { Breusch-Godfrey LM Test }(p)=0.129^{*}, \\
\text { White Test }(p)=0.177^{*}, \text { Ramsey RESET Test } \\
(p)=0.106^{*}, \text { JB test }(p)=0.293\end{array}$} \\
\hline $\mathrm{ECT}_{\mathrm{t}-1}$ & $-0.364^{*}$ & \\
\hline Sabit & $2.583^{*}$ & \\
\hline
\end{tabular}

Not: *0.05 için istatistiksel olarak anlamlılı̆̆ı, JB; Jarque-Bera normallik testi olasılık değgerini ifade etmektedir. Tahminlerdeki otokorelasyon ve değişen varyans sorunları, Newey-West yöntemi ile giderilmeye çalışılmıştır.

Tablo 7'de model 1 için anlamlı neticeler elde edilememiştir ve covid sayısı ile BİST_mali endeksi arasında kısa dönem için ilişkili çıkmamıştır. Bunun dışında kalan dört model için anlamlı sonuçlar belirlenmiştir. Tüm modellerde hata düzeltme terimlerinin katsayıları negatif ve istatistiki açıdan anlamlı olarak elde edilmiştir. Diğer bir ifadeyle; modellerin, hata düzeltme mekanizmaları doğru bir şekilde işlemektedir. Model 2 için uzun dönemde birlikte hareket eden serilerin arasındaki kısa dönemde ortaya çıkan sapmaların \%38.6'sı, model 3 için \%40.6'sı, model 4 için \%37.5'i ve model 5 için \%36.4'ü giderilmekte ve seriler tekrardan uzun dönemde denge değerine yakınsamaktadır. Yani; kısa dönemde ortaya çıkan sapmalar ortadan kalkmakta ve değişkenler tekrar uzun dönemde denge değerine yaklaşmaktadır. Kısa dönemde katsayılar uzun dönem katsayılarına göre daha yüksek çıkmıştır. Yani; covid vaka sayısının kısa dönemde etkisi daha yüksek, uzun dönemde biraz daha azalarak seyretmektedir.

\section{SONUÇ ve TARTIŞMA}

Çalışmada, küresel finans piyasalarında geniş kapsamlı ve kayda değer şok dalgalarına yol açan Covid-19'un Türkiye'deki iktisadi faaliyetlerin üstündeki negatif etkileri göz önünde bulundurulduğunda, finansal piyasaların temel taşı hisse senedi piyasalarına olan etkisinin belirlenmesi amaçlanmıştır. İlgili amaç doğrultusunda, [16.03.2020 - 07.05.2021] günlük veriler için, Covid-19 vaka sayılarının BİST sektör endeksleri üzerindeki etkilerini tespit etmeye yönelik uzun dönem ilişkilerin test edilmesi için Bayer-Hanck (2013) eşbütünleşme analizi ve kısa dönem ilişkilerin test edilmesi için hata düzeltme modeli kullanılmıştır. Bayer ve Hanck (2013) eşbütünleşme testi sonuçlarına göre; Bist-mali endeksi dışında kalan hizmet, sanayi, turizm ve ulaştırma endeksleri için hesaplanan iki Fisher Test istatistiği değeri bütün endeksler için kritik değerden büyük olduğundan covid sayıları ile ilgili endeksler arasında eşbütünleşme ilişkisinin olduğu belirlenmiştir. Elde edilen eşbütünleşme bulgusu literatürde Şenol ve Zeren (2020) tarafından yapılan Fourier eşbütünleşme testi sonuçlarına göre hisse senedi piyasalarıyla Covid-19 salgını arasında uzun dönemli bir ilişkinin bulunduğuna yönelik bulgularıyla paralellik göstermektedir. Ayrıca Barut ve Kaygın (2020) tarafından yapılan çalışmada BIST100 endeksi ve covid vaka sayısı arasındaki eşbütünleşme varlığına yönelik tespitleri açısından da paralel sonuçlar elde edilmiştir. FMOLS yöntemine göre eşbütünleşme denklemi katsayı tahmini otokorelasyon ve değişen varyans problemleri Newey-West yöntemiyle çözülmeye çalışılmıştır. Analiz neticesinde, covid vaka sayısı sektör endeksleri üzerinde genel anlamda olumsuz bir etki yaratırken, BİST_sanayi endeksi üzerinde daha fazla azaltıcı olumsuz etkiye yol açmıştır. En az olumsuz etki ulaştırma sektörü için elde edilmiştir. Özellikle ulaştırma sektörü için elde edilen bulgular, Öztürk ve diğerleri (2020) tarafından elde edilen ulaşım, turizm, spor metal ürünleri, makine, bankacılık ve sigortacılık sektörlerinin, salgından en fazla etkilenmiş olan sektörler olduğu bulgusu ile çelişmektedir. Uzun dönemli ilişkiye yönelik genel anlamla elde edilen bulgular, Al-Awadhi ve diğerleri (2020) tarafından Çin Borsasında yapılan panel regresyon çalışmasının sonuçları ile paralellik göstermektedir. Yazarlar covid 19 vaka sayıları ve ölüm sayılarının hisse senedi getirileri üzerinde negatif bir etki yarattı̆̆ını tespit etmişlerdir. Diğer yandan Onali (2020) çalışmasında kurulan VAR modeli ile elde edilen sonuçlara göre ise İtalya ve Fransa'da raporlanan ölüm sayılarının Dow Jones getirilerinin üstünde negatif yönlü bir etkisinin bulunduğunu tespit etmişlerdir ve elde edilen bulgularla uyumludur. Kotishwar (2020) tarafından yapılan çalışmanın sonuçlarına göre ise, 


\section{A. Ertuğrul Ayranc1 - G. Arı 13/4 (2021) 3770-3785}

Covid-19'un incelenen tüm borsa endeksleri ile kritik seviyede olumsuz yönde ve uzun vadeli ilişkisinin bulunduğu ortaya konulmuştur ve çalışmanın sonuçları ile paralellik göstermektedir.

Kısa dönem ilişkiler açısından hata düzeltme modeli tahmin edilmiş ve hata düzeltme terimlerinin katsayıları negatif ve istatistiki açıdan anlamlı olduğundan, hata düzeltme mekanizmasının çalıştığı belirlenmiştir. Buradan hareketle şu yorum yapılabilmektedir: Kısa vadede ortaya çıkan sapmalar yok olmakta ve değişkenler yeniden uzun vadede denge değerine yakınsamaktadır. Kısa dönemde katsayılar, uzun dönem katsayılarına göre daha yüksek çıkmıştır. Yani; covid vaka sayılarının etkilerinin kısa dönemde daha yüksek olduğunu, uzun dönemde ise bu etkilerin azalarak devam ettiğini söylemek mümkündür. Kısa dönemde azaltıcı etki daha yüksek çıkmıştır, dönem uzadıkça azaltıcı etki düşüş göstermektedir. Kısa dönemdeki şiddetli azaltıcı etki Liu ve diğerleri (2020) tarafından yapılan çalışmada kısa vadede hisse senetlerinin virüs salgınının sonrasında hızlı bir şekilde düşüş yaşadığı yönündeki bulguları ile paralellik göstermektedir. Aynı zamanda Topçu ve Gülal (2020) tarafından yapılan çalışmada salgının, gelişmekte olan borsaların üstündeki negatif yönlü etkilerinin kademeli şekilde azaldığının tespit edilmesi, çalışmanın bulgularıyla paralellik göstermektedir.

Görüleceği üzere, ekonomik krizler gibi salgınlar da yatırımcıların kaybetme korkusunu ve piyasalardaki olumsuzlukları körüklemekte, piyasalarda uzun dönemli kayıpların yaşanmasına neden olmaktadır. Pandeminin büyük belirsizliği, piyasaların oldukça oynak ve öngörülemez hale gelmesine neden olması ile hisse senetlerinin Covid-19 olarak onaylanmış vakalardaki büyümeye negatif yönlü tepkiler gösterdiği sonucu Zhang ve diğerleri (2020) ve Ashraf (2020) tarafından yapılan çalışmalardan elde edilen bulgular ile paralellik göstermektedir. Yine bulgulara paralel olacak şekilde Kılıç (2020) tarafından yapılan çalışmada da Covid-19 virüsünün, BİST sektörel endeks getirileri üzerinde genel olarak negatif yönlü etkilerinin bulunduğu tespit edilmiştir. Diğer yandan çalışmanın bulguları, Ahmed (2020) tarafından Pakistan borsasında doğrulanmış Covid-19 vakalarının ve ölüm sayılarının borsa performansına etkilerinin göz ardı edilebilecek seviyede olduğuna yönelik bulguları ile çelişki göstermektedrir. Bu durum Waheed ve diğerleri (2020) tarafından Pakistan borsasında yapılan çalışmada da görülmektedir. Araştırmacıların, pandemi başlangıcında borsada bir düşüş olduğu fakat hükümet tarafından önleyici tedbirler alındıktan sonra durumun daha iyiye gittiğini belirtmişlerdir.

Sonuçlardan da anlaşılacağı üzere; BİST'te sektör endeksleri pandemi sürecinde düşüş yaşamıştır. Pandemi kaynaklı yaşanan belirsizlikler beraberinde yatırımcıların riskten kaçınma düzeyini ve güven algısını da etkilemesi kaçınılmazdır. Türkiye ekonomisi sanayi sektöründe faaliyet gösteren büyük firmaların krizlere karşı daha dayanıklı oldukları ve krizi fırsata çevirmeyi veya en azından kriz sırasındaki konumlarını korumayı başardıkları birçok çalışmada ortaya konmuştur. Bununla birlikte, pandeminin beklenmedik bir dış etkisi olmuştur ve finansal piyasalar küresel olarak gerilemiştir. Hassas sektörler için kalıcı politikaların üretilmesi gerekmektedir ve sürecin uzayabileceği durumlarda tarımsal destek paketleri gibi programlar ivedilikle uygulamaya konulmalıdır. Bu süreçteki en önemli eşik noktasının üretim zincirinin sürekliliği olduğu unutulmamalıdır ve bunun devamının sağlanması üzere bir an önce çalışma kesimini izole edecek ve koruyacak önlemler alınmalıdır. Salgının boyutu ve uzun vadeli finansal etkileri göz önünde bulundurulduğunda, gelir transferleri, borç ertelemeleri, vergi/kredi kolaylıkları, doğrudan fonlama, garantili borç şeklindeki önlemlerin arttırılması gerekliliği kaçınılmazdır. Piyasalarda güven kalmadığında ilk çarpıcı etki finansal piyasalara yansıyacaktır. Küresel salgınlar şeklindeki öncesinden tahmin edilemeyen durumların ülkelerin finansal varlıklarını direkt olarak etkilemesi öngörülmektedir. Yatırımcıların daha güvenilir yatırım araçları arayışından çıkışının yarattığı panik ortamı fiyatların düşmesine ve oynaklığın artmasına sebebiyet vermektedir. Diğer yandan araştırmanın kapsamı ve salgının henüz bitmemesi sebebiyle incelenen dönem aralığı sınırlı kalmaktadır. Dolayısıyla gelecekte gerçekleşecek vaka sayılarındaki değişim, iyileşme ve aşılanma süreci ile birlikte yeni verilerin daha geniş bir dönem aralığında incelenmesi, pandeminin ilgili sektörler üzerindeki etkisini karşılaştırmalı olarak tespit etmeye ilişkin bilgi sağlamak açısından faydalı olacaktır. 


\section{KAYNAKÇA}

Ahmed, S. (2020). "Impact of Covid-19 on Performance of Pakistan Stock Exchange", Preprints, 1(1):1-12.

Aktürk, L. N., Yılancı, V. ve Bozoklu, Ş. (2014). "Spot ve Türev Piyasalar Arasındaki Etkileşim: Türkiye Örneği", 1. Karadeniz ve Balkan Ekonomik ve Politik Araştırmalar Sempozyumu, 3-4 Eylül 2014, Bülent Ecevit Üniversitesi, Zonguldak. 675-687.

Al-Awadhi, A. M., Al-Saifi, K., Al-Awadhi, A. ve Alhammadi, S. (2020). "Death and Contagious Infectious Diseases: Impact of the COVID-19 Virus on Stock Market Returns". Journal of Behavioral and Experimental Finance, 27(1):1-5.

Alber, N. (2020). "The Effect of Coronavirus Spread on Stock Markets. The Case of The Worst 6 Countries", https://papers.ssrn.com/sol3/papers.cfm?abstract id=3578080 1-11.

Ashraf, B. N. (2020), "Stock Markets' Reaction to Covid-19: Cases or Fatalities?", Research in International Business and Finance, 54(1): 1-7.

Arı, A. (2016). “Türkiye'deki Ekonomik Büyüme ve İşsizlik İlişkisinin Analizi: Yeni Bir Eşbütünleşme Testi”, Siyaset, Ekonomi ve Yönetim Araştırmaları Dergisi, 4 (4): 57-67.

Banerjee, A., Dolado, J. ve Mestre, R. (1998). “Error-correction mechanism tests for cointegration in a singleequation framework", Journal of Time Series Analysis, 19(3): 267-283.

Barut, A. ve Kaygın, C. Y. (2020). “Covid-19 Pandemisinin Seçilmiş Borsa Endeksleri Üzerine Etkisinin İncelenmesi”. Gaziantep Üniversitesi Sosyal Bilimler Dergisi, 19 (1):59-70.

Bayer, C. ve Hanck, C. (2013). "Combining Non-Cointegration Tests", Journal of Time Series Analysis, 34(1): 8395.

Bloom, D. ve Canning, D. (2000). The Health and Wealth of Nations, Science, 287(1):1207-1209.

Boswijk, H. P. (1994). “Testing for an Unstable Root in Conditional and Structural Error Correction Models”, Journal of Econometrics, 63(1): 37-60.

Chaouachi, M. ve Chaouachi, S. (2020). "Current Covid-19 Impact on Saudi Stock Market: Evidence from an Ardl Model", International Journal of Accounting, Finance, Auditing, Management and Economics, 1(1): 113.

Dang, H-A. ve Nguyen, C. V. (2020). “Gender Inequality during the COVID-19 Pandemic: Income, Expenditure, Savings, and Job Loss", Discussion Paper Series, IZA DP No:13824,1-30.

Engle, R. F. ve Granger, C. W. (1987). “Co-integration And Error Correction: Representation, Estimation, And Testing", Econometrica, 55(2):251-276.

Fernandes, N. (2020). "Economic Effects of Coronavirus Outbreak (COVID-19) on the World Economy", IESE Business School Working Paper No: WP-1240-E, 1-33.

Finansal İstikrar Raporu (2020). Finansal İstikrar Raporu Kasım 2020, Erişim: 21 Mart 2021, https://www.tcmb.gov.tr/wps/wcm/connect/TR/TCMB+TR/Main+Menu/Yayinlar/Raporlar/Finansal+ Istikrar+Raporu/2020/Sayi+31.

Gülhan, Ü. (2020). “Covid-19 Pandemisine BIST 100 Reaksiyonu: Ekonometrik Bir Analiz", Electronic TurkishStudies, 15(4): 497-509.

Govindaraju, V. G. ve Tang, C. F. (2013). “The Dynamic Links Between CO2 Emissions, Economic Growth And Coal Consumption in China and India", Applied Energy ,104(1):310-318.

He, Q., Liu, J., Wang, S. ve Yu, J. (2020). “The Impact of Covid-19 on Stock Markets”, Economic and Political Studies, 8(3): 275-288.

İlley, A. ve Kenneth R. (2020). “Negative Interest Rate Policy in The Post COVID-19 World." Erişim: 12 Mart 2021, https://voxeu.org/article/negative-interest-rate-policy-post-covid-19-world.

Johansen, S. (1988). "Statistical Analysis of Cointegration Vectors", Journal of Economic Dynamics and Control, 12(2-3): 231-254.

Kandil Göker, İ. E., Eren, B. S. ve Karaca, S. S. (2020). "The Impact of the COVID-19 (Coronavirus) on The Borsa Istanbul Sector Index Returns: An Event Study", Gaziantep University Journal of Social Sciences, 1(1): 14-41. 


\section{A. Ertuğrul Ayranc1 - G. Arı 13/4 (2021) 3770-3785}

Kılıç, Y. (2020). "Borsa İstanbul'da COVID-19 (Koronavirüs) Etkisi”, Journal of Emerging Economies and Policy, 5(1): 66-77.

Kızılgöl, Ö. (2006). “Türkiye' de Büyüme Oranı ile İşsizlik Arasındaki İlişkisi”, Akademik Fener Dergisi, 6(1): 5469.

Kotishwar, A. (2020). "Impact of Covid-19 Pandemic on Stock Market with Reference to Select Countries -A Study", Academy of Accounting and Financial Studies Journal, 24(4): 1-9.

Lahmiri, S. ve Bekiros, S. (2020). "The Impact of COVID-19 Pandemic Upon Stability And Sequential Irregularity of Equity and Cryptocurrency Markets, Chaos Solitons Fractals, 138(1): 1-7.

Liu, H., Manzoor, A., Wang, C.Y., - Zhang, L. (2020). “The Covid-19 Outbreak and Affected Countries Stock Markets Response", Environmental Research and Public Health,17(1): 1-19.

Morales, L. ve Andreosso-O'Callaghan, B. (2020). “Covid19: Global Stock Markets "Black Swan", Critical Letters in Economics \& Finance, 1(1): 1-14.

OECD (2020), Evaluating The Initial Impact of COVID-19 Containment Measures on Economic Activity, The Organisation for Economic Co-operation and Development (OECD), Erişim: 13 Mayıs 2021, http://www.oecd.org/coronavirus/policy-responses/evaluating-the-initialimpact-of-covid-19containment-measures-on-economic-activity-b1f6b68b/.

Onali, E. (2020). “COVID-19 and Stock Market Volatility,. SSRN Electronic Journal, 1(1):1-24.

Öztürk, Ö., Şişman, M. Y., Uslu, H. ve Çıtak, F. (2020). “Effect of COVID-19 Outbreak on Turkish Stock Market: A Sectoral-Level Analysis", Hitit University Journal of Social Sciences Institute, 13(1): 56-68.

Sansa, Nuhu A. (2020), "The Impact of the Covid - 19 on The Financial Markets: Evidence from China and Usa", Electronic Research Journal of Social Sciences and Humanities, 2(1): 29-39.

Shahbaz, M., Sahbi F. ve Öztürk, İ. (2013). “Coal Consumption, Industrial Production and CO2 Emissions in China and India", Munich Personal RePEc Archive, Paper No: 50618:1-19.

Srivastava, V. K. (2020). “Anatomy of Stigma: Understanding COVID-19”, Social Change, 50(3):385-398.

Şenol, Z. ve Zeren, F. (2020). "Coronavirus (Covid-19) and Stock Markets: The Effects of the Pandemic on the Global Economy", Avrasya Sosyal ve Ekonomi Araştırmaları Dergisi, 7(4): 1-16.

Tayar, T., Gümüştekin, E., Dayan, K. ve Mandi, E. (2020). “Covid-19 Krizinin Türkiye'deki Sektörler Üzerindeki Etkisi: Borsa İstanbul Sektör Endeks Araştırması", Van Yüzüncü Yıl Üniversitesi, Sosyal Bilimler Üniversitesi Dergisi, Salgın Hastalıkları Özel Sayı, 1(1):293-320.

Topcu, M. ve Gülal, Ö. S. (2020). “The Impact of Covid-19 on Emerging Stock Markets”, Finance Research Letters, 36(1):1-5.

Waheed, R. S., Suleman, S. S., Khan, M. K. (2020). “The Impact of Covid-19 on Karachi Stock Exchange: Quantile-On-Quantile Approach Using Secondary and Predicted Data", Journal of Public Affairs,1(1): $1-6$.

Yan, B., Stuart, L., Tu, A. ve Zhang, Q. (2020). “Analysis of The Effect of Covid-19 on The Stock Market and Investing Strategies", https://papers.ssrn.com/sol3/papers.cfm?abstract_id=3563380, 1-17.

Zhang, D., Hu, M. ve Ji, Q. (2020). "Financial Markets under the Global Pandemic of COVID-19". Finance Research Letters, 36(1): 1-6.

Zeren, F., ve Hizarc1, A. (2020). "The Impact of COVID-19 Coronavirus on Stock Markets: Evıdence From Selected Countries", Muhasebe ve Finans İncelemeleri Dergisi, 3(1): 78-84. 